Kraichynska Oleksandra, Maslova Yuliia. Academic migration and its influence on the social development of countries (on the example of the National University „Ostroh Academy”). Pedagogy and Psychology of Sport. 2020;6(4):138-150. elSSN 2450-6605. DOI http://dx.doi.org/10.12775/PPS.2020.06.04.013

https://apcz.umk.pl/czasopisma/index.php/PPS/article/view/PPS.2020.06.04.013 https://zenodo.org/record/4362489

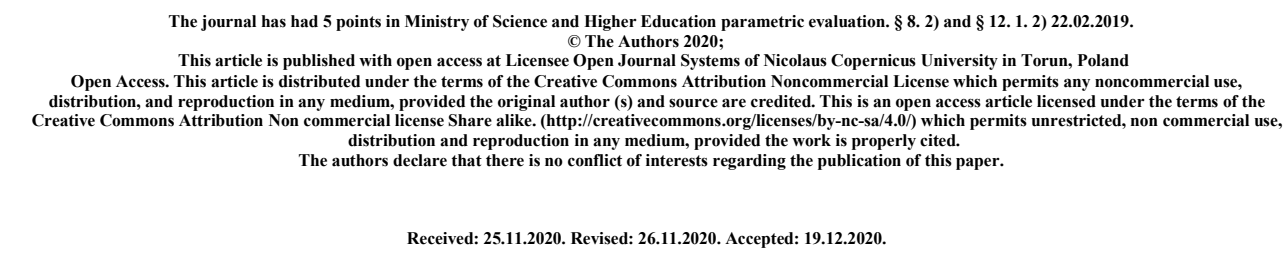

UDC 331.556.4:378

УДК 331.556.4:378

АКАДЕМІЧНА МІГРАЦІЯ ТА ЇЇ ВПЛИВ НА СОЦІАЛЬНИЙ РОЗВИТОК КРАЇН (НА ПРИКЛАДІ НАЦІОНАЛЬНОГО УНІВЕРСИТЕТУ «ОСТРОЗЬКА АКАДЕМІЯ»)

\title{
ACADEMIC MIGRATION AND ITS INFLUENCE ON THE SOCIAL DEVELOPMENT OF COUNTRIES (ON THE EXAMPLE OF THE NATIONAL UNIVERSITY „OSTROH ACADEMY”)
}

\author{
Oleksandra Kraichynska, Yuliia Maslova \\ National University of Ostroh Academy, Ostroh, Ukraine \\ Крайчинська Олександра, Маслова Юлія \\ Національний університет «Острозька академія»
}

\begin{abstract}
Академічна міграція як найбільш розвинена форма інтернаціоналізації освітньої сфери сприяє інтеграції особистості в міжнародне освітнє співтовариство. Вона сприяє розвитку міжкультурних компетенцій, підвищує шанси на більш високу професійну самореалізацію студентів та викладачів, підвищення ї професіоналізму у викладанні, дослідженнях та самоврядуванні. У статті висвітлено різницю між такими поняттями як «академічна міграція» та «студентська міграція». Визначено основні причинно-наслідкові зв'язки між академічною міграцією та економікою країн, що приймає мігрантів. Через опитування освітнього товариства Національного університету «Острозька академія» було проаналізовано настрої студентів та викладачів щодо навчання та стажування закордоном.
\end{abstract}


Ключові слова: академічна міграція, студентська міграція, міжнародна освітня міграція, освтіні мігранти, глобалізація.

Academic migration as the most developed form of internationalization of the educational sphere promotes the integration of the individual into the international educational community. It promotes the development of intercultural competencies, increases the chances for higher professional self-realization of students and teachers, increasing their professionalism in teaching, research and self-government. The article highlights the difference between such concepts as "academic migration" and "student migration". The main causal links between academic migration and the economy of host countries have been identified. A survey of the educational society of the National University "Ostroh Academy" analyzed the attitudes of students and teachers regarding study and internship abroad.

Key words: academic migration, student migration, international educational migration, educational migrants, globalization.

Постановка проблеми. У зв'язку із посиленими глобалізаційними процесами у світовій економіці стає все більш актуальним питання збільшення обсягів та зростання темпів міграції людських ресурсів. Міграція сьогодні - це мільйони людей по всьому світу. Зараз визначальним чинником соціальноекономічного розвитку тих чи тих країн стали висококваліфіковані фахівці та вчені, що мігрують по робочим чи навчальним причинам. Це призводить до зросту якості країн імміграції, але, в той же час, до занепаду країн еміграції.

В умовах активізації процесів інтелектуальної міграції важливим завданням для України стає збереження державного інтелектуального потенціалу. Його виконання вимагає комплексного та досконалого розуміння сутності міграційної мотивації, яка спричиняє еміграцію висококваліфікованих фахівців.

На даний момент у світі питання академічної міграції гостро обговорюється серед наукового суспільства. В умовах глобалізації явище академічної міграції набуває все більшої значущості у зв'язку із низкою причин економічного та соціального характеру. Стрімкий розвиток технічних, економічних, соціальних та господарських зв'язків між країнами процесів приводять до розширення можливостей навчання та академічних обмінів за кордоном, збільшення попиту на послуги високоякісної міжнародної освіти. Академічна міграція має бути досліджена через низку соціальних та економічних проблем, що спричинені швидким, глобальним потоком молоді закордон, серед яких студенти, найбільш активної частини населення, Оскільки основна частина мігрантів це молодь, серед яких студенти та викладачі.

У сучасних умовах міграційна проблематика стає надзвичайно актуальним питанням, яке впливає на характер та сутність міграційних відносин, визначає перспективи та роль держав в міжнародному середовищі. Для певних факторів вона перетворюється на важливу загрозу національній безпеці, оскільки виїзд людських ресурсів за кордон напряму підриває потенціал країн, їхню здатність до інтенсивного розвитку та адаптації до співіснування в глобальному просторі. В цьому контексті найбільш загрозливими стають процеси міжнародної 
інтелектуальної міграції. Україна сьогодні є одним з провідних країн-донорів мігрантів. Її втрати від відповідних процесів величезні - особливо з точки зору виїзду за кордон висококваліфікованих кадрів, представників наукової та творчої еліти. Виправлення ситуації вимагає комплексної державної стратегії дій, яка може бути реалізована лише за умов розуміння відповідними органами сутності проблеми. Мова йде не лише про вивчення практичних аспектів інтелектуальної міграції українців, масштабів та причин цих процесів. Увага наукового середовища має бути приділена загальнотеоретичним аспектам цієї проблематики - лише на основі такої бази можлива розробка дієвої відповіді на міграційну загрозу.

Аналіз останніх досліджень і публікацій. У своїх теоретичних дослідженнях теми академічної та, зокрема, студентської міграції праці торкались такі науковці. Так, Л.І. Безтелесна [4] розглядає освітню міграцію як інструмент реалізації стратегічного управління людським капіталом. Л. Семів [15] проектує вплив міжнародної освітньої міграції на територіальні економічні системи. Тенденції міжнародної освітньої міграції у контексті процесів глобалізації також є предметом дослідження Л.А. Жураковської [7] та В.М. Філатова [17].

Географія процесів інтелектуальної міграції українських громадян відображається в низці робіт загального характеру. Цю тему підіймали в своїх статтях Т. І. Алексєєва та К. В. Горбаньова [1], 3. П. Бараник та І. О. Романенко [3], О. А. Малиновська [9; 10], Л. І. Оппельд [12].

Досліджуючи тенденції академічної міграції, Л. Жураковська підкреслює, що освітніх мігрантів, тобто іноземних студентів, можна вважати найбажанішою категорією мігрантів, оскільки вони представлені, як правило, найбільш обдарованими та мотивованими молодими людьми, готовими сприймати нові знання і технології. Для більшості економічно розвинених країн освітня міграція стає одним із засобів формування людського капіталу, необхідного для розвитку національних економік, водночас $є$ потужним геополітичним ресурсом, що використовується для розповсюдження і просування культури, технологій країн навчання іноземців [7, с. 234]. Людина, набуваючи нові навики та знання, стає головним рушієм економічного поступу. 3 огляду на це кожна країна зацікавлена у збільшенні людського потенціалу. Як наслідок, актуальності набуває освітня міграція в умовах глобалізації, як зазначає Д. Кучеренко [8, с. 30]. Крім того, проблеми освітньої міграції є предметом наукових досліджень В. Іонцева, О. Біляковської, О. Малиновської. В. Іонцев визначають освітню міграцію як територіальне пересування 3 одного населеного пункту (держави) в інший з метою навчання (або стажування) в одному з навчальних закладів населеного пункту (держави) в’їзду. Після завершення навчання особа, що виїжджала на навчання в іншу країну, зобов'язана повернутися на Батьківщину. Водночас мають місце випадки неповернення, які класифікуються як «витік умів» [5, с. 233]. О. Біляковська констатує, що метою освітньої міграції є здобуття освіти, і виділяє характерні 
риси освітньої міграції: короткостроковість, більш-менш чітко окреслені часові рамки, належність до певної вікової групи, добровільність переміщення [5, с. 231]. О. Малиновська виділяє міжнародну навчальну міграцію як переміщення іноземних студентів [9, с. 27].

Актуальність досліджуваної проблематики. Тематика освітньогеографічного аспекту міграції українських інтелектуальних ресурсів за кордон досі не була об'єктом спеціального наукового дослідження. Таким чином, вона стає не вирішеною частиною загальної проблеми комплексного дослідження вітчизняних міграційних процесів, розробка якої має бути покладена в основу вироблення спеціальної стратегії освітньо-міграційної політики України. Це визначає практичну актуальність даної роботи, покликаної вдосконалити розуміння сутності явища академічної міграції в українських реаліях.

Метою статті $\epsilon$ характеристика процесів академічної міграції громадян України з точки зору формування освітньої міграції в умовах глобальної нестабільності, іiі розвитку та наслідків. Глобальна фінансова та економічна криза поставила ряд нових запитань для науковців, які вивчають освітні міграційні процеси.. В цьому контексті на основі статистичних даних отриманих шляхом анкетування студентів Національного університету «Острозька академія» визначаються найпопулярніші держави призначення для наших співгромадян-освітян, що реалізовують свої міграційні прагнення; вивчаються причини та характерні риси, які роблять ці країни такими привабливими для мігрантів. Окремо розглядаються такі категорії учасників міграційних процесів, як наукова еліта та студентство, оскільки їхній міграційний рух має свої специфічні риси, що впливають на визначення його кінцевої точки, тривалості перебування за кордоном та потенціалу до повернення на Батьківщину.

Викладення основного матеріалу дослідження. Глобалізація в сучасних умовах є домінуючою тенденцією, яка спричиняє значні трансформації в усіх сферах суспільного життя. І важливими є не тільки факти змін, але й ті впливи, які здійснюють глобальні процеси на соціальну систему загалом і систему освіти зокрема. Глобалізація, розвиток інтеграційних процесів сприяли тому, що освітні послуги перетнули національні межі. Природним закономірним процесом, що дає змогу збалансувати економічну, соціальну, політичну i духовну сфери суспільства, $є$ міграція населення.

Міграція населення (від лат. «migratio» - «переселення») - переміщення людей через кордони тих чи інших територій зі зміною місця проживання назавжди або на більш-менш тривалий час [2]. Серед різновидів міграції виділяють освітню міграцію, яка $\epsilon$ переважно тимчасовим переселенням 3 метою отримання освіти та підвищення кваліфікації за межами адміністративнотериторіальної одиниці постійного проживання [7, с. 113-117].

Ми вважаємо, що академічна міграція - це соціально-економічний та демографічний процес, що є частотою змін перебування, що здійснюється науковцями, професорсько-викладацьким складом, студентами та іншими 
особами всередині країни та за їі межами 3 метою тимчасової або постійної зміни місця роботи, підвищення освітньо-кваліфікаційного рівня, проведення наукових досліджень, післядипломної освіти, стажування тощо. Характеризуючи географічні напрямки міграційних переміщень українців, відзначимо, що протягом тривалого часу основним реципієнтом українських інтелектуальних мігрантів вважалися держави-сусіди, в першу чергу Російська Федерація та Польща [3 с. 225]. Така оцінка ситуації відповідає загальному розподілу потоку трудових мігрантів з України в інші держави. Втім детальне вивчення специфіки міграції наукових та висококваліфікованих кадрів демонструє іншу картину. Дослідження 2012-2013 років, реалізоване в рамках проекту Інституту відкритого суспільства, показало, що основним місцем призначення українських інтелектуальних мігрантів були США (30 \% в 2012 р., $33 \%$ в 2013 р.), Росія (27\% та $24 \%$ ) та Німеччина (16 \% та $18 \%$ ). Також в списку відзначились Ізраїль (9\% та $7 \%$ ), Канада (10\% та $8 \%$ ), Польща (5\% та $6 \%$ ) та Чехія (3\% та $4 \%$ ) [16]. Це підтверджують й дані статистики щодо інтелектуальної міграції на початковому етапі відновлення української державності. Наприклад, протягом 1991-1995 років українські доктори наук в основному виїжджали до Російської Федерації (115 осіб) та США (105 осіб). Значно меншою за масштабами була міграція науковців до Ізраїлю (34 особи), Німеччини (10 осіб) та Польщі (9 осіб) [14, с. 17].

Розглядаючи міграцію науковців - докторів та кандидатів наук, — Я. Петрова відзначає, що вона розділяється практично порівну між країнами ближнього й далекого зарубіжжя. До половини мігрантів-науковців виїхали в країни СНД і Балтії, решта - в Ізраїль, США, Німеччину, Канаду, Францію. Найбільше число докторів наук — 42,2 \% — станом на 2007 рік виїхали в Російську Федерацію. Подібні пропорції зберігаються в міграційних потоках переважно молодих науковців. Серед країн Центральної Свропи вибір зазвичай робиться на користь Угорщини, Польщі, Чехії [13, с. 128]. При цьому представники гуманітарних спеціальностей в першу чергу орієнтуються на країни Західної Європи, а технічних - на еміграцію до США [13, с. 130]. Статистичні дані за 1996-2012 роки, зібрані центром CEDOS, дозволяють детальніше вивчити масштаби міграції українських науковців до конкретних країн. За цей період до США виїхали 183 доктори та 354 кандидати наук; до Російської Федерації 212 докторів та 298 кандидатів наук; до Ізраїлю - 94 доктори та 275 кандидатів наук; до Німеччини — 53 доктори та 213 кандидатів наук; до Канади - 14 докторів та 103 кандидати наук; до Польщі - 37 докторів та 30 кандидатів наук [11]. Удеяких випадках вони змогли зайняти належне місце в структурі місцевої науково-освітньої діяльності. Наприклад, в Німеччині з 2005 до 2011 року кількість українських професорів, наукового та художнього персоналу зросла на 81,7 \% — з 431 до 783 осіб [11, с. 13].

Таким чином, географічний вимір міграції українських науковців не повністю співпадає з показниками загальних процесів трудової міграції. Країни-сусіди України з Центральної та Східної Свропи є другорядним місцем призначення 
українських інтелектуальних мігрантів. Останні орієнтуються на певні стандарти життя, шукають за кордоном кращі можливості для реалізації свого потенціалу в науковому середовищі - тому не дивно, що вони в першу чергу орієнтуються саме на США та Німеччину, а не Польщу або Чехію. Процеси міграційних переміщень на територію країн-сусідів мають свою специфіку. Говорячи про міграцію української інтелектуальної еліти в цьому напрямку, Л. Оппельд звертає увагу на швидкі темпи зростання кількості «маятникових» висококваліфікованих емігрантів. Він наголошує, що сьогодні багато українських вчених живуть і за кордоном, і на Батьківщині, постійно мігруючи між двома країнами. Ця тенденція особливо характерна для регіонів Західної України. Наприклад, у Львові та інших західноукраїнських містах багато вчених і викладачів ЗВО працюють як в Україні, так і в Польщі, Угорщині, Словаччині тощо [12].

Окрім науковців важливу складову інтелектуального потенціалу держави становлять студенти. Враховуючи доволі вузькі можливості достойного працевлаштування молоді в Україні та вкрай низькі заробітні плати початківців, еміграційні настрої серед молодих українців доволі поширені - за даними соціологічних служб, від 56 \% представників цієї категорії респондентів готові емігрувати за кордон [9, с. 15]. Міграційні пріоритети студентської молоді майбутніх випускників 3ВО, які становлять потенційну кадрову базу вітчизняної науки та високотехнологічного виробництва, дозоляє оцінити анкетування, організоване в Дніпропетровську в 2013 році. Популярністю в якості місця призначення міграції серед студентів користувалися Російська Федерація (25\%), США (14\%) та Німеччина (10\%) [10, с. 44]. Проведене в 2015-2016 роках експертне опитування представників університетів міста Чернігова демонструє зміни в географічних вподобаннях українських студентів, перспективних мігрантів після подій Революції Гідності та початку російської агресії. Згідно з отриманими даними, найбільш привабливою для мігрантів країною є Німеччина — їй відали перевагу 44 \% від загальної кількості студентів, які підтвердили свої міграційні наміри. Також популярністю користуються США (24\%), Франція (14\%) та Великобританія (14\%). Серед інших країн респонденти називали Польщу, Данію, Китай та Сінгапур [14, с. 20].

Наведені вище дані демонструють міграційні пріоритети українських студентів, які прагнуть взяти участь в процесах безповоротної міграції. Втім існує й інший вимір міграційного руху студентства — тимчасовий, реалізований в рамках навчання за кордоном. Академічна міграція української молоді відзначається своєю специфікою. При цьому за останні десять років ситуація в цьому секторі суттєво змінювалась. Так, в 2009 році беззаперечним лідером серед країн навчання українських студентів була Німеччина (8,5 тис. осіб). На другому місці перебувала Російська Федерація (4,2 тис. осіб), на третьому (3 певним відставанням) - Польща (2,8 тис. осіб). Також популярністю в українців користувалися Чехія, США та Франція - в кожній $з$ цих держав 
навчалися понад тисяча наших співвітчизників. Станом на 2013 рік лідируючі позиції зайняли Польща та Німеччина. В цих державах навчалися по 9-9,5 тис. молодих українців. В Росії продовжували навчання близько 4,5 тис. осіб [1, с. 19]. В Чехії, Італії та Канаді їхня кількість була значно меншою та становила від 1,5 до 1,7 тис. осіб.

Статистика за 2013-2014 навчальний рік показує певні зміни в цьому секторі, викликані в першу чергу активізацією навчальної міграції до Польщі. В цей період в польських ЗВО здобувала освіту найбільша кількість українських студентів (15 тисяч осіб). Значні студентські спільноти українців також існували в Німеччині (9 тис. осіб) та Росії (6 тис. осіб). Менша кількість українських студентів навчалась в Канаді та Чехії (по 2 тис. осіб), Італії (1,9 тис. осіб), США (1,5 тис. осіб), Іспанії (1,4 тис. осіб), Франції (1,3 тис. осіб), Великобританії (1 тис. осіб) [4, с. 15]. В Австралії, Австрії та Угорщині в цей період навчалося від 0,8 до 1,1 тис. українців [1, с. 19].

Аналіз динаміки змін кількості українських студентів за кордоном в наступні роки дозволяє підтвердити наші висновки про наявність більш привабливих для української молоді країн. Одні держави поступово втрачають прихильність українських абітурієнтів. За даними дослідження центру CEDOS, до них в першу чергу належать США, Молдова та Швеція. Інші країни (Німеччина, Росія, Франція, Угорщина та Болгарія) з перемінним успіхом тримають число громадян України серед своїх студентів приблизно на однаковому рівні. Проте в більшості із названих вище держав спостерігається зростання кількості українців, які навчаються на їхній території в університетах. Серед них зазвичай згадуються Польща, Чехія, Італія, Іспанія, Канада, Австрія, Великобританія, Австралія, Швейцарія тощо [11]. На рубежі 2000-2010 рр. саме Польща перетворилася на основного реципієнта молодих українців. За період 2009-2013 рр. їхня кількість в польських ВНЗ збільшилась приблизно в п’ять разів - 3 2,8 до 14,9 тис. осіб. Після подій Революції Гідності ця тенденція продовжувалась. У 2016 році кількість українських студентів, які навчалися в польських університетах, становила вже понад 30 тис. осіб, тобто збільшилась за два роки вдвічі. Темпи приросту цієї категорії мігрантів становили до 50 \% на рік. Достатньо високими вони були у випадку Канади, доходячи до показників у 22-27\%. У порівнянні з 2013 роком кількість українських студентів в цій державі також збільшилась вдвічі. Втім в даному випадку абсолютні цифри значно менші і складають лише близько 3 тис. студентів станом на 2015-2016 навчальний рік.

Число українців на студіях в іноземних університетах станом на 2014/2015 навчальний рік становило 59648 осіб. Серед найбільш бажаних для навчання країн, як і раніше, залишаються Польща, Німеччина, Росія, Канада, Італія, Чехія, США, Іспанія, Австрія, Франція та Угорщина. Динаміка зростання 3 2009 по 2015 роки склала 129\%. Якщо порівнювати два останні роки, то приріст складає майже 29\% або ж 13266 осіб. Причому 2/3 цього приросту склали саме українці, які навчаються в польських університетах. Вони 
показали найбільш стрімке збільшення, як в абсолютному, так і відносному показниках, - 314951 до 22833 особи. Також значний відносний та абсолютний приріст українських громадян на студіях демонстрували канадські, чеські та італійські університети (Рис. 1) [11].

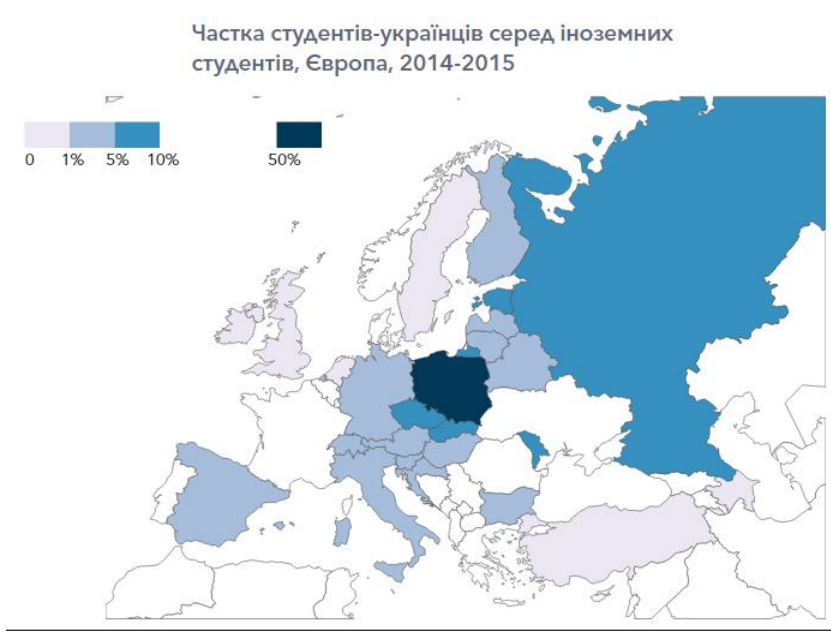

Рис. 1. Частка студентів-українців серед іноземних студентів, Свропа, 2014-2015 pp.
Багато країн Свропи також впроваджують державну політику щодо залучення інтелектуальних мігрантів. Серед головних чинників, за рахунок яких вони приваблюють українських висококваліфікованих спеціалістів, вітчизняні дослідники виділяють створення сприятливого середовища для акумуляції наукових знань та започаткування міжнародних програм 3 інформаційного обміну для підвищення

Дюсерело: cedos.org.uа

кваліфікації вченого [3, с. 225]. Одним 3 основних чинників, який зазвичай приваблює іноземних студентів, є відсутність плати за навчання у державних ВНЗ або ж іiї порівняно низький рівень. До країн, які пропонують іноземцям саме такі умови, належать Німеччина, Чехія та частково Франція [11]. В той же час, окрім приваблюючих факторів, покликаних витягнути 3 країн, що розвиваються, інтелектуальні ресурси та поставити їх на службу розвинутих держав, існують й протилежні тенденції. Деякі американські та західноєвропейські університети, які надають освітні послуги іноземним студентам, висувають певні вимоги, спрямовані на те, щоб після завершення навчання студенти повертались на певний часовий період на Батьківщину [12]. Таким чином вони намагаються забезпечити нормалізацію темпів модернізації країн, що розвиваються. В умовах глобалізованого світу такий підхід не $\epsilon$ виключно проявом месіанського лібералізму - взаємозалежність держав світу вимагає від лідерів міжнародної спільноти слідкувати за гармонійним розвитком всіх їі частин.

Вибіркове обстеження за умов обмеженості статистичної інформації про переміщення молоді на навчання за кордон $є$ досить дієвим методом отримання даних про тенденції, що існують у цій сфері. Проведене в межах дослідження опитування студентської молоді дає змогу уявити масштаби та перспективи освітньої міграції у досліджуваному регіоні. Тому на основі вищезазначених дослідженнях, було проведене власне із студентами Національного університету «Острозька академія». За цільову групу обрано студентів, що досягли повноліття (18-21 років), зараз навчається на бакалавраті та має 
високий рівень знання іноземної мови. Було обрано 50 студентів факультету романо-германських мов. Обрання цього сегменту пояснюється тим, що навчання за кордоном потребує знання іноземної мови, а досягнення повноліття та здобуття ступеня бакалавра $є$ тими умовами, що значно розширюють можливості навчання за кордоном.

Результатами анонімного анкетування студентської молоді, що навчається на 3-4 курсах Національного університету «Острозька академія» (50 осіб, гендерно збалансована група), було отримано результати, які дали змогу отримати загальне уявлення про те, чи цікавляться студенти навчанням за кордоном та міжнародними програмами обміну, які країни займають провідні позиції за інтересом студентів, якими факторами керуються потенційні студенти-мігранти у виборі країни навчання та чи корисною для них стала участь у подібних програмах, стажуваннях чи літніх школах.

Перед студентами були поставлені запитання щодо навчання закордоном. Зокрема на питання «Чи розглядаєте Ви продовження навчання закордоном?» 24 з 50 респондентів відповіли «Так», 19 з 50 не впевнені у своїх вподобаннях та 7 з 50 надали відповідь «Ні». У полі для пояснення відповідей студенти 3 негативними відповідями пояснили, що не розглядають таку можливість через фінансову причину, сімейні фактори та національні ідеї.

Основне питання було поставлено наступним чином: «В яких країнах Ви бажали б продовжити навчання? Поясніть свою думку.» (Рис.2). Лідером серед відповідей стала Польща (22 відповіді) і пояснили це близьким розташуванням, легкою мовою для вивчення та дешевизною навчання. Друге місце зайняла Німеччина (19 відповідей) через доступність вивчення мови, високий рівень життя. Канада (6 відповідей) була обрана через найбільшу українську діаспору, кількість пропозицій навчання для українців. Чехія (5 відповідей) та Франція (4

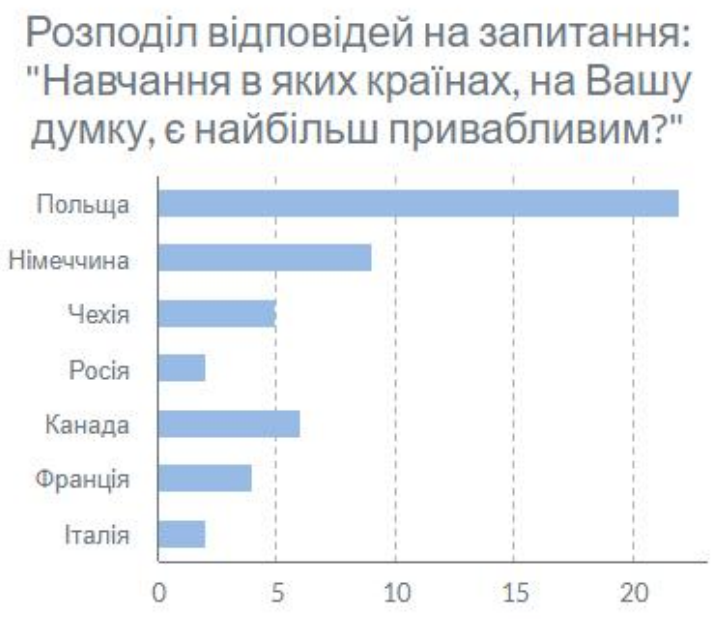

Рис. 2 Розподіл відповідей на запитання: «В яких країнах Ви бажали б продовжити навчання? Поясніть свою думку.»

Джерело: складено автором за власними даними відповіді) були обрані через особистісні вподобання щодо країни. Росія (2 відповіді) та Італія (2 відповіді) залишились без пояснень.

Таким чином, навчальні заклади країн $\epsilon$ C $\epsilon$ найбільш привабливими для студентів Національного університету «Острозька академія» (у сумі близько $\quad 40 \% \quad$ голосів респондентів).

Нам необхідно визначити причини виїзду студентів закордон, тому перед респондентами було поставлене питання: « Які фактори для Вас $€$ 
визначальними для навчання закордоном?» Відповіді показали, що найпопулярнішим фактором $\epsilon$ можливість кращого працевлаштування в майбутньому (24 відповіді). Важливим для студентів є престижність самого закладу (13 відповідей) та можливість отримання грантів, стипендій та пільг для іноземців (9 відповідей). Як показало опитування, вартість навчання не грає велику роль при виборі місця навчання (4 відповіді). Джерелами пошуку інформації щодо навчання закордоном стали інтернет-ресурси: офіційні сайти українських ВНЗ, в якому вони навчаються (18 відповідей). Серед опитаних 15 чоловік отримують інформацію з освітніх інтернет-платформ, а також із сайтів закордонних навчальних закладів (10 відповідей) та розпитують знайомих і друзів (7 відповідей).

Питання «Чи плануєте ви повертатись на Батьківщину після навчання закордоном?» допомогло нам визначити настрої студентства щодо «витоку умів». Більша половина опитуваних (27 відповідей) планують залишитись на постійне проживання після навчання закордоном. 16 респондентів бажають повернутись назад для реалізації своїх можливостей в Україні. Інші не визначились 3 своїми бажаннями (7 відповідей).

Проаналізувавши усі відповіді, ми можемо зробити висновок, що рівень зацікавленості українських студентів у навчанні за кордоном досить високий, а найбільший інтерес становлять навчальні заклади Європейського Союзу.

Високий ступінь довіри 3 боку студентів до інформації про можливості навчання за кордоном, що надається «рідним» українським навчальним закладом, має бути використаний для спрямування міграційних потоків в академічному напрямі до вузів-партнерів, що посилить позитивний вплив цього процесу на національну економіку i дасть змогу стримати самоорганізований виїзд молоді на навчання за кордон із подальшою зміною постійного місця проживання.

Висновки 3 даного дослідження. У сфері академічної міграції склалась ситуація, де міграційна привабливість формується спрощеними умовами або преференціями для здобуття освіти, якими можуть скористатися українські студенти. Беззаперечним лідером тут залишається Польща, в якій за останні роки в кілька разів збільшився приток української студентської молоді. В цілому наявні дані засвідчують більшу орієнтацію українських інтелектуальних мігрантів на західний міграційний напрямок - особливо після подій Революції Гідності та початку російської агресії. Вони їдуть в держави, які користуються репутацією лідерів світу, де можна повноцінно реалізувати свій потенціал та амбіції, підвищити свою професійну кваліфікацію та забезпечити належні умови проживання. Відтак запобігти подальшому поширенню міграційного явища можна лише за рахунок модернізації внутрішньої української сфери освіти та науки у відповідності до тих стандартів, які пропонують зазначені країни. В той же час слід використовувати наявний міграційний потік для покращення іміджу України в 
якості місця проживання освічених та здібних людей, підкреслюючи таким чином ще раз цивілізаційний вибір нашої держави.

В сучасних умовах глобалізації процеси зворотної та тимчасової інтелектуальної міграції (у форматі обміну досвідом, участі в грантовій діяльності) $\epsilon$ неодмінною умовою включення держави до світового наукового середовища. Це стає важливим елементом підвищення потенціалу країни до інтенсивного розвитку на міжнародній арені. В той же час безповоротна еміграція інтелектуальної еліти стає провідною безпековою загрозою для держав, які таким чином втрачають свій потенціал. Той факт, що Україна також безпосередньо страждає від цього явища, напряму визначає актуальність вивчення міграційної проблематики для вітчизняної науки.

\section{Список використаної літератури}

1. Алексєєва Т. І., Горбаньова К. В. Інтелектуальна еміграція з України. Причорноморські економічні студії. - 2016. - Вип. 11. - С. 18-21.

2. Бакаев О. В., Римаренко Ю. І. Міграція // Юридична енциклопедія : [у 6 т.] / ред. кол. Ю. С. Шемшученко (відп. ред.) [та ін.] - К. : Українська енциклопедія ім. М. П. Бажана, 1998-2004. — ISBN 966-749-200-1.

3. Бараник 3. П., Романенко I. О. Інтелектуальна міграція населення України: статистичний аспект. // Науковий вісник Херсонського державного університету. - Серія: Економічні науки. - 2014. - Вип. 6, ч. 5. - С. 223-227.

4. Безтелесна Л.І. Академічна мобільність як інструмент реалізації стратегічного управління ресурсами [Електронний ресурс] / Л.І. Безтелесна // Вісник національного університету водного господарства та природокористування. — 2016. - Вип. 1(73). - С.11-12. Режим доступу: http://ep3.nuwm.edu.ua/4422/1/Безтелесна\%20Л.\%20I.\%20Академічна\%20мобільність\%20зах.pdf

5. Біляковська О. Освітня міграція українців до Польщі: соціопсихологійний аспект / О. Біляковська // Соціально-економічні та етнокультурні наслідки міграції для України: зб. матеріалів наук.-практ. конф. (Київ, 27 вересня 2011 року). - К., 2011. - С. 231-237.

6. Горожанкина Н. А. Международная интеллектуальная эмиграция из Днепропетровского региона (геосоциологический компонент). Псковский регионологический журнал. - 2013. - № 16. - С. 43-48.

7. Жураковська Л.А. Тенденції освітньої міграції в контексті глобалізації економічного розвитку [Електронний ресурс] // Демографія та соціальна економіка. - 2014. - № 1(21). Режим доступу: http://dse.org.ua/ arhcive/21/20.pdf.

8. Кучеренко Д. Стратегії розвитку освітніх систем країн світу: [монографія] / Д. Кучеренко, О. Мартинюк. - К.: ІПК ДСЗУ, 2011.-312 с.

9. Малиновська О. А. Зовнішня міграція громадян України в умовах поглиблення євроінтеграційних процесів: виклики та шляхи реагування / Національний інститут стратегічних досліджень. URL: http://www.niss.gov.ua/content/articles/files/bezviz-6eaa1.pdf (дата звернення 7.07.2018).

10. Міграція в Україні: факти і цифри / Представництво МОМ в Україні; упорядник О. Малиновська - Київ - 2016. - 32 с.

11. Олександра Слободян, Єгор Стадний. Українські студенти за кордоном: скільки та чому? [Електронний ресурс] // CEDOS. - 2016. - Режим доступу: https://cedos.org.ua/uk/articles/ukrainski-studenty-za-kordonom-skilky-ta-chomu

12. Оппельд Л. І. Сучасні тенденції міжнародної інтелектуальної міграції в умовах євроінтеграції. Ефективна економіка.- 2013. - № 3. - С. 12-33. 
13. Петрова Я. Інтелектуальна міграція в Україні: мотивація та наслідки для суспільства. Міграція і толерантність в Україні: зб. ст. / за ред. Ярослава Пилинського. К.: Стилос, 2007. С. 127-132.

14. Полковниченко С., Курочка В. «Відплив умів» з України як загроза національній безпеці. Проблеми і перспективи економіки та управління. - 2016.- № 4 (8).- С. 16-22.

15. Семів Л. Освітня міграція як фактор розвитку територіальних міграційних систем: національний та європейський аспект / Л. Семів // Соціально-економічні проблеми сучасного періоду України. - 2013. - Вип. 3(101). - С. 244-253.

16. Соціологічне опитування сімей міжнародних трудових мігрантів у межах проекту // Open Society Institute. Higher Education Support Program. Project Wealth, Poverty and Life Satisfaction in Transition Societies, -2013.

17. Філатов В.М. Специфічні ознаки освітньої міграції та іiї місце в структурі міграційних потоків [Електронний ресурс] / В.М. Філатов, Я.В. Ромашова // Ефективна економіка. - 2014. № 2. - Режим доступу: http://www.economy.nayka.com.ua/?op=1\&z=2785.

\section{Rererences}

1.Aleksyeyeva T. I., Horban"ova K. V. Intelektual"na emihraciya z Ukrayiny. Prychornomors"ki ekonomichni studiyi. - 2016. - Vyp. 11. - S. 18-21.

2.Bakaev O. V., Rymarenko Yu. I. Mihraciya // Yurydychna encyklopediya : [u 6 t.] / red. kol. Yu. S. Shemshuchenko (vidp. red.) [ta in.] - K. : Ukrayins"ka encyklopediya im. M. P. Bazhana, 1998-2004. — ISBN 966-749-200-1.

3.Baranyk Z. P., Romanenko I. O. Intelektual"na mihraciya naselennya Ukrayiny: statystychnyj aspekt. // Naukovyj visnyk Xersons"koho derzhavnoho universytetu. Seriya: Ekonomichni nauky. - 2014. - Vyp. 6, ch. 5. - S. 223-227.

4.Beztelesna L.I. Akademichna mobil"nist" yak instrument realizaciyi stratehichnoho upravlinnya resursamy [Elektronnyj resurs] / L.I. Beztelesna // Visnyk nacional"noho universytetu vodnoho hospodarstva ta pryrodokorystuvannya. - 2016. - Vyp. 1(73). $\quad-\quad$ S.11-12. $\quad$ - $\quad$ Rezhym dostupu: http://ep3.nuwm.edu.ua/4422/1/Beztelesna\%20L.\%20I.\%20Akademichna\%20mobil" nist"\%20zax.pdf

5.Bilyakovs"ka O. Osvitnya mihraciya ukrayinciv do Pol"shhi: sociopsyxolohijnyj aspekt / O. Bilyakovs"ka // Social"no-ekonomichni ta etnokul"turni naslidky mihraciyi dlya Ukrayiny: zb. materialiv nauk.-prakt. konf. (Kyyiv, 27 veresnya 2011 roku). - K., 2011. - S. 231-237.

6.Horozhankyna N. A. Mezhdunarodnaya yntellektual"naya эmyhracyya yz Dnepropetrovskoho rehyona (heosocyolohycheskyj komponent). Pskovskyj rehyonolohycheskyj zhurnal. - 2013. - № 16. - S. 43-48.

7.Zhurakovs"ka L.A. Tendenciyi osvitn"oyi mihraciyi v konteksti hlobalizaciyi ekonomichnoho rozvytku [Elektronnyj resurs] // Demohrafiya ta social"na ekonomika. - 2014. - № 1(21). - Rezhym dostupu: http://dse.org.ua/ arhcive/21/20.pdf.

8.Kucherenko D. Stratehiyi rozvytku osvitnix system krayin svitu: [monohrafiya] / D. Kucherenko, O. Martynyuk. - K.: IPK DSZU, 2011. - 312 s.

9.Malynovs"ka O. A. Zovnishnya mihraciya hromadyan Ukrayiny v umovax pohlyblennya yevrointehracijnyx procesiv: vyklyky ta shlyaxy reahuvannya / 
Nacional"nyj instytut stratehichnyx doslidzhen". URL: http://www.niss.gov.ua/content/articles/files/bezviz-6eaa1.pdf (data zvernennya 7.07.2018)

10.Mihraciya v Ukrayini: fakty i cyfry / Predstavnyctvo MOM v Ukrayini; uporyadnyk O. Malynovs"ka - Kyyiv - 2016. - 32 s.

11.Oleksandra Slobodyan, Yehor Stadnyj. Ukrayins"ki studenty za kordonom: skil"ky ta chomu? [Elektronnyj resurs] // CEDOS. - 2016. - Rezhym dostupu: https://cedos.org.ua/uk/articles/ukrainski-studenty-za-kordonom-skilky-ta-chomu 12.Oppel"d L. I. Suchasni tendenciyi mizhnarodnoyi intelektual"noyi mihraciyi v umovax yevrointehraciyi. Efektyvna ekonomika.- 2013. - № 3. - S. 12-33.

13.Petrova Ya. Intelektual"na mihraciya v Ukrayini: motyvaciya ta naslidky dlya suspil"stva. Mihraciya i tolerantnist" v Ukrayini: zb. st. / za red. Yaroslava Pylyns"koho. K.: Stylos, 2007. S. 127-132.

14.Polkovnychenko S., Kurochka V. «Vidplyv umiv» z Ukrayiny yak zahroza nacional"nij bezpeci. Problemy i perspektyvy ekonomiky ta upravlinnya. - 2016.- № 4 (8).- S. 16-22.

15.Semiv L. Osvitnya mihraciya yak faktor rozvytku terytorial"nyx mihracijnyx system: nacional"nyj ta yevropejs"kyj aspekt / L. Semiv // Social"no-ekonomichni problemy suchasnoho periodu Ukrayiny. - 2013. - Vyp. 3(101). - S. 244-253.

16.Sociolohichne opytuvannya simej mizhnarodnyx trudovyx mihrantiv u mezhax proektu // Open Society Institute. Higher Education Support Program. Project Wealth, Poverty and Life Satisfaction in Transition Societies, - 2013.

17.Filatov V.M. Specyfichni oznaky osvitn"oyi mihraciyi ta yiyi misce v strukturi mihracijnyx potokiv [Elektronnyj resurs] / V.M. Filatov, Ya.V. Romashova // Efektyvna ekonomika. - 2014. - № 2. - Rezhym dostupu: http://www.economy.nayka.com.ua/?op=1\&z=2785. 